\title{
Properties of Modified Wood According to Treatment Technology and Thermo-Vacuum Process for Birch (Betula pendula Roth) Veneers
}

\author{
Anete Meija-Feldmane, ${ }^{\mathrm{a}}$ Ignazia Cuccui, ${ }^{\mathrm{b}}$ Ilze Irbe,${ }^{\mathrm{c}}$ Andris Morozovs, ${ }^{\mathrm{a}}$ and \\ Uldis Spulle $^{\text {a }}$
}

\begin{abstract}
Thermally modified birch (Betula pendula Roth) veneers that had been subjected to wood treatment technology (WTT) or thermo vacuum (TV) processes were compared in this study. After modification of veneers in the range of temperatures from $160^{\circ} \mathrm{C}$ to $218^{\circ} \mathrm{C}$ and times from $0.5 \mathrm{~h}$ to $3 \mathrm{~h}$, the color, mass loss, density, tensile strength, hygroscopicity, and decay resistance against brown rot fungus Coniophora puteana were determined. Treatment regimes with the greatest mass loss were at 217 ${ }^{\circ} \mathrm{C}$ for $3.0 \mathrm{~h}$ in TV $(7.8 \%)$ and $160{ }^{\circ} \mathrm{C}$ for $0.8 \mathrm{~h}$ in the WTT $(6.7 \%)$. As expected, wood mass loss correlated well with moisture exclusion efficiency (MEE) in all relative humidity $(\mathrm{RH})$ environments $(r=0.95$ to 0.99). Strength loss in the WTT was considerable compared to the TV process (57\% and $40 \%$, respectively). The resistance against brown rot fungus was moderate with a mass loss of $12 \%$ to $33 \%$. Among the investigated samples, the regime 217/3.0/TV showed the best resistance against brown rot fungus and acceptable other properties.
\end{abstract}

Keywords: Birch; Thermal modification; Wood treatment technology; Thermo vacuum treatment; Decay resistance

Contact information: a: Latvia University of Life Sciences and Technologies (LLU), Liela Street 2, Jelgava, LV-3001, Latvia; b: BioEconomy Institute CNR-IBE, via Biasi, 75 - 38010 San Michele all'Adige -(TN), Italy; c: Latvian State Institute of Wood Chemistry, Dzerbenes Street 27, Riga, LV-1006, Latvia;

* Corresponding author: a.meija.feldmane@gmail.com

\section{INTRODUCTION}

With an increasing awareness of global climate change and greenhouse gas emissions, among which $\mathrm{CO}_{2}$ is the crucial one, there is increasing interest in wood materials that can accumulate and store carbon dioxide. The longer the wood material can be used, the longer it stores carbon; therefore several techniques to prolong the life span of wood materials have been developed (Hildebrandt et al. 2017).

Plywood is an engineered cross-glued wood material made from peeled veneers. World production of plywood reached 107.4 million $\mathrm{m}^{3}$ in 2017 (Raute 2017). The properties of plywood are mainly determined by the characteristics of veneers such as wood species and technological features (Gilbert et al. 2017). Veneer swells in a humid environment and shrinks when it is drying, which can provoke internal stresses in plywood and also its delamination.

Wood thermal treatment at temperatures of $160{ }^{\circ} \mathrm{C}$ to $240{ }^{\circ} \mathrm{C}$ is the most acceptable industrial method for wood modification. The wood thermal modification increases the dimensional stability of veneer by increasing its hydrophobicity. Chemical changes in wood due to the thermal modification depend on the duration of treatment and temperature. 
Wood species, temperature, presence of oxygen in a reaction environment, and process duration are the main factors that determine the properties of the modified wood (Esteves and Pereira 2009; Sandberg et al. 2017). The thermal modification processes are mainly carried out in a dry environment, in inert gas, or a moist environment (Sandberg and Kutnar 2016; Sandberg et al. 2017). There are several commercial treatments, among which Thermowood $®$ is the most popular (Shi et al. 2007). WTT is classified as a closed method that operates at lower temperatures (Irbe et al. 2017).

Organic acids formed from hemicellulose during thermal treatment cause hydrolysis of wood cells and wall carbohydrates, as well as lignin regrouping that affects chemical and physical properties of wood (Gérardin 2016). If these decomposition products are promptly evacuated by vacuum, the process lowers wood degradation (Candelier et al. 2013), especially in the case of thick veneers (Sandak et al. 2016). Several commercial processes use vacuum, such as Silvapro® (Rep et al. 2012), SmartHeat ${ }^{\circledR}$ (Van Acker et al. 2011), and Termovuoto® (Ferrari et al. 2013).

Silver birch is a widely used wood species in Latvia for plywood and furniture manufacturing as well as a raw material for the pulp and paper industry; it has limited biological durability and dimensional stability. By decreasing the drawbacks, the usage of silver birch could be widened, and thermal treatment is a methodology that increases biological durability and dimensional stability. Silver birch has been treated in WTT process (Grinins 2016) but has not been widely investigated in the thermo-vacuum (TV) process.

The objective of the present research is the comparison of thermally modified (Betula pendula Roth) veneers treated in the WTT and TV processes.

\section{EXPERIMENTAL}

\section{Materials and Methods}

The experiments were carried out in the Laboratory of Wood Drying and Thermal Treatment at the BioEconomy Institute CNR IBE, San Michele all'Adige, Italy (TV modification and moisture exclusion efficiency), the Laboratory of Wood Biodegradation and Protection of the Latvian State Institute of Wood Chemistry (WTT, microscopy and decay tests), and the Department of Wood Processing in LLU. Experiments were conducted with rotary-cut birch veneers from JSC "Latvijas Finieris," Riga, Latvia.

\section{Wood treatment technology (WTT)}

Thermal modification of birch veneers with the dimensions of $1000 \mathrm{~mm} \times 350 \mathrm{~mm}$ $\times 1.5 \mathrm{~mm}$ was conducted with wood treatment technology under the previously determined optimal regime of $160{ }^{\circ} \mathrm{C}, 0.8 \mathrm{~h}(160 / 0.8 / \mathrm{WTT})$, and $500 \mathrm{kPa}$ to $900 \mathrm{kPa}$ pressure in water vapor environments in packs of 10 sheets per each. In total 60 samples were treated. The process classified as a moist, closed thermal treatment technology was described in detail previously by Grinins et al. (2016).

\section{Thermo vacuum technology (TV)}

Thermo vacuum technology (TV) can be classified as a dry, open thermal treatment under vacuum (Allegretti et al. 2012; Sandak et al. 2015). Rotary - cut $600 \mathrm{~mm} \times 600 \mathrm{~mm}$ $\times 1.5 \mathrm{~mm}$ birch veneers were treated in four experimental regimes (Table 1) under $25 \mathrm{kPa}$ pressure, although this process was modified so that veneers were treated under a 
convective heat regime between aluminum plates in packs of 6 to 10 layers, $\sim 40$ samples per regime in total.

Table 1. Experimental Regimes

\begin{tabular}{|c|c|c|c|}
\hline Regime & Temperature $\left({ }^{\circ} \mathrm{C}\right)$ & Treatment Time $(\mathrm{h})$ & Treatment Type \\
\hline $160 / 0.8 / \mathrm{WTT}$ & 160 & 0.8 & WTT \\
\hline $204 / 2.0 / \mathrm{TV}$ & 204 & 2.0 & TV \\
\hline $214 / 2.0 / \mathrm{TV}$ & 214 & 2.0 & TV \\
\hline $217 / 3.0 / \mathrm{TV}$ & 217 & 3.0 & TV \\
\hline $218 / 0.5 / \mathrm{TV}$ & 218 & 0.5 & TV \\
\hline
\end{tabular}

The WTT experimental regime (160/0.8/WTT) was previously found as optimal for birch veneers regarding decay resistance (Irbe et al. 2017) and other properties (Grinins 2016). TV regimes were chosen to repeat mass loss of 160/0.8/WTT (214/2.0/TV), as well as to have $2 \%$ more $(217 / 3.0 / \mathrm{TV})$ and $2 \%$ (204/2.0/TV) less mass loss.

\section{Laboratory Characterization}

Mass loss

Mass loss was determined by weighing each sample before and after the treatment, and it was calculated according to Eq. 1,

$$
M L=\frac{m_{m}-m_{0}}{m_{0}} \cdot 100 \%
$$

where $m_{0}$ is the mass of oven-dry untreated wood samples $(\mathrm{kg})$ and $m_{m}$ is the mass of oven-dry modified wood samples $(\mathrm{kg})$.

\section{Density}

Density was determined according to ISO 13062-2 (2014). Standard deviation and coefficient of variation were calculated for the analysis of the results.

\section{Color}

A MicroFlash 200D portable spectrophotometer (DataColor, Lawrenceville, NJ, USA) suitable for direct determination of CIE $L * a * b *$ color coordinates according to ISO/CIE 11664-4 (2008) was used for measurement over an $18 \mathrm{~mm}$ diameter spot with a standard light source D65 and an observer angle of $10^{\circ}$. Color was also measured with a Minolta CM-2500d spectrophotometer with D65 light source and d/8 measuring geometry and $10^{\circ}$ standard observer (Konica Minolta, Tokyo, Japan). Each of the 30 samples was measured 3 times at the same spot before and after the heat treatment.

The total color change $\Delta \mathrm{E}$ between treated and untreated samples was calculated according to Eq. 2,

$$
\Delta E=\sqrt{(\Delta L)^{2}+(\Delta a)^{2}+(\Delta b)^{2}}
$$

where $L^{*}$ indicates the lightness in the range from black (0) to white (100) and $a^{*}$ and $b^{*}$ define the position in the green-red and blue-yellow axis respectively.

\section{EMC and MEE}

Equilibrium moisture content was measured on samples with dimensions of $40 \mathrm{x}$ $20 \mathrm{~mm}$ according to ISO 13061-1 (2014). One sample was cut from each of the treated and 
untreated veneers (a total of 20 samples for each regime) and conditioned in a climatic chamber at a temperature of $20{ }^{\circ} \mathrm{C}$ and $30 \%, 65 \%$, and $80 \%$ relative humidity (RH).

The Moisture Exclusion Efficiency (MEE) of samples equilibrated at each condition was estimated by Eq. 3,

$$
M E E=\frac{E M C_{N T}-E M C_{H T}}{E M C_{N T}}
$$

where $E M C_{N T}(\%)$ is the EMC of untreated reference samples and $E M C_{H T}(\%)$ is the EMC of treated samples.

The MEE value expressed the relative variation of EMC of treated wood equilibrated at $\mathrm{RH} 30 \%, 65 \%$, and $80 \%$ ( $\mathrm{MEE}=0 \%$ indicated no EMC variation; $\mathrm{MEE}=$ $100 \%$ indicated an EMC value of $0 \%$ ).

\section{Tensile strength}

Tensile strength of veneers parallel to the grain was determined according to GOST 20800-75 (1976). Twenty random samples with the dimensions of: width $20 \mathrm{~mm}$; length (grain direction) $200 \mathrm{~mm}$; thickness $1.5 \mathrm{~mm}$ were cut from both treated and untreated veneers. To prevent the samples from slipping out of the clamps, pieces of plywood with the dimensions $20 \mathrm{~mm} \times 50 \mathrm{~mm} \times 4.5 \mathrm{~mm}$ were glued on both sides of the veneers and on both ends of samples using one-component polyurethane glue. Afterwards, the samples were conditioned at $20 \pm 3{ }^{\circ} \mathrm{C}$ and $65 \pm 5 \%$ relative humidity. A tensile strength test was conducted with the INSTRON 5967 device (Instron, Norwood, MA, USA) with a constant speed of approximately $1 \mathrm{~mm}$ per minute to obtain a rupture of samples in $60 \pm 30 \mathrm{~s}$.

\section{Decay resistance}

Decay resistance was determined according to European Prestandard ENV 12038 (2002) using brown rot fungus Coniophora puteana BAM Ebw 15. The fungus was cultivated on a medium which contained $5 \%$ malt extract concentrate and $2 \%$ Fluka agar. 10 samples of each regime with the dimensions of $50 \mathrm{~mm} \times 25 \mathrm{~mm} \times 1.5 \mathrm{~mm}$ were aseptically placed on $3 \mathrm{~mm}$ steel supports in Petri dishes on fungal mycelium and incubated at $22 \pm 2{ }^{\circ} \mathrm{C}$ and $70 \pm 5 \% \mathrm{RH}$ for 6 weeks. After cultivation, the samples were removed from the culture vessels, brushed free of mycelium, and oven dried at $103 \pm 2{ }^{\circ} \mathrm{C}$. Percentage weight loss (WL) of the samples was the measure for the extent of fungal degradation.

\section{Microscopy}

Light microscopy (LM) was performed on 10 samples from thermally modified and unmodified birch veneers with the dimensions of $20 \mathrm{~mm} \times 20 \mathrm{~mm} \times 1.5 \mathrm{~mm}$. Before microscopy, the samples were soaked for $24 \mathrm{~h}$ in distilled water to soften the wood structure and make it sliceable. Wood sample cuts $(15 \mu \mathrm{m}$ to $30 \mu \mathrm{m})$ were obtained with a razor blade. Microscopy was made with a Leica DMLB light microscope (Leica Microsystems, Mannheim, Germany) at $400 \times$ magnifications. The images were taken with a Leica DFC490 video camera, using Image-Pro Plus 6.3 software for picture analysis (Media Cybernetics, Inc., Silver Spring, MD, USA).

\section{Statistics}

To determine a statistically significant difference among groups of data, one-factor ANOVA with a confidence level of 0.05 was considered. 
The CORREL function in MS EXCEL was used to estimate how two or more variables were related to another.

\section{RESULTS AND DISCUSSION}

\section{Mass Loss}

Mass loss is the main indicator of the intensity of thermal modification. Mass loss is caused mainly by the degradation of hemicellulose due to its lower degree of polymerization and higher reactivity because of its amorphous structure (Hill 2006; Gérardin 2016). The average mass loss for each regime can be seen in Fig. 1.

The TV modification in a dry environment was less severe than in a moist environment of the WTT process. The 160/0.8/WTT regime had twice the loss of mass of the 204/2.0/TV regime despite $1.2 \mathrm{~h}$ shorter modification duration and $44{ }^{\circ} \mathrm{C}$ lower treatment temperature. This indicated the prevalence of hydrolysis processes in the wood thermal decomposition. Water and acetic acid formed by wood decomposition were easily evacuated from thin veneer by vacuum. The dependence of mass loss from wood species, process environment, temperature, and heat impact duration in wood thermal modification was ascertained by several authors and is well-known (Esteves and Pereira 2009; Xu et al. 2019).

Veneers` mass loss in TV increased with modification temperature and duration, and differences between 217/3.0/TV and 218/0.5/TV emphasized the importance of the duration.

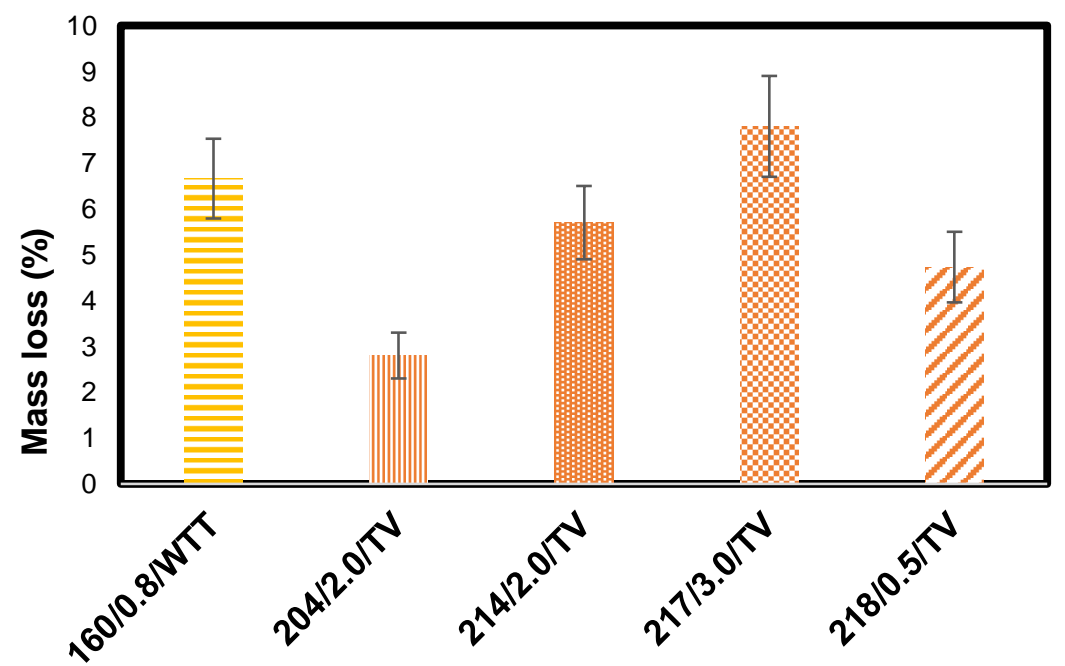

Fig. 1. Mass loss after thermal modification of birch veneer samples (STDEV error bars)

According to Grinins (2016) concerning the mass loss for birch veneers, $160 / 0.8$ /WTT was $6.3 \%$, which is the same as that observed with treated veneers at $6.7 \%$. If the mass and dimensions of the sample increase, for example for birch planks, mass loss at the same regime 160/0.8/WTT becomes considerably greater - reaching 16\% (Biziks et al. (2016) and it is important for plywood production if thicker veneers are used. According to Chaouch et al. (2013), mass loss occurs mainly due to deacetylation of strongly acetylated glucuronxylan which causes liberation of acetic acid, which then catalyzes depolymerization of less - ordered carbohydrates. 


\section{Density}

The density of the investigated samples is shown in Table 2. The density of untreated birch wood was $598 \pm 42 \mathrm{~kg} / \mathrm{m}^{3}$ and coincided with the previously observed density of $568 \mathrm{~kg} / \mathrm{m}^{3}$ (Ruponen et al. 2015).

Table 2. Average, Standard Deviation, and Variation of Veneer Density

\begin{tabular}{|l|c|c|c|}
\hline Sample & Average Density $\left(\mathrm{kg} / \mathrm{m}^{3}\right)$ & Standard Deviation $\left(\mathrm{kg} / \mathrm{m}^{3}\right)$ & Variation $(\%)$ \\
\hline Unmodified & 598 & 42.0 & 7.1 \\
\hline $160 / 0.8 /$ WTT & 583 & 43.0 & 7.4 \\
\hline $204 / 2.0 /$ TV & 584 & 34.9 & 6.0 \\
\hline $214 / 2.0 /$ TV & 621 & 48.7 & 7.8 \\
\hline $217 / 3.0 /$ TV & 574 & 38.6 & 6.7 \\
\hline $218 / 0.5 /$ TV & 615 & 35.2 & 5.7 \\
\hline
\end{tabular}

Using one-factor ANOVA analysis, $\mathrm{F}=5.38>\mathrm{F}_{\text {crit. }}=2.24(\mathrm{p}=0.0001)$, and therefore the treatment affected veneer density above its natural variation. The variation between samples did not exceed 20\% and was considered acceptable. Sandberg et al. (2013) stated that the density of wood during thermal modification decreases from 5\% to $15 \%$, thus additionally affecting its strength. Kotilainen (2000) also implies that thermally modified wood has a lower density than untreated wood and deviation is high.

\section{Color}

During the modification process, wood became darker and the variation depended on the treatment temperature. As shown in Fig. $2, L^{*}$ decreased on average by half after thermal treatment and reached 42 to 53 units, which coincided with the findings by Lovric et al. (2014). The mildest treatment regime 204/2.0/TV had the highest $L^{*}$ value among the treated samples. The modified veneers` surface color $a^{*}$ component was several times greater than for unmodified ones. After modification, veneers became more reddish, especially the 160/0.8/WTT veneers. As cellulose and hemicellulose do not absorb visible light (Hon and Minemura 2001), these changes implied an alteration of phenolic structures in lignin and extractives during the thermal modification process. Veneers' surface color $b^{*}$ component slightly decreased with the increase in the severity of the thermo-vacuum process and in WTT - treated veneers.

The total color changes $(\Delta E)$ depending of the mass loss can be seen in Fig. 3. Visually visible changes were considered if $\Delta E$ was greater than 3.5 units (Mokrzycki and Tatol 2011). Hemicellulose was the component that was damaged most during heat treatment. Consequently, the relative content of lignin in heat-treated wood increased accordingly, which might explain darker colors (Lovrič et al. 2014). Brischke et al. (2007) described that the sum of lightness parameter and yellow-blue axis parameter $\left(L^{*}+b^{*}\right)$ correlate with treatment regime for beech wood $\left(\mathrm{R}^{2}=0.951\right)$. The total color changes in this research correlated $(\mathrm{r}=0.98)$ well with mass loss, and the most severe was the regime 217/3.0/TV, followed by 160/0.8/WTT. As it is observed, color changes did not occur as a result of increase in temperature. Also, the treatment duration and treatment method were substantial. The results can be seen in Fig. 3. 

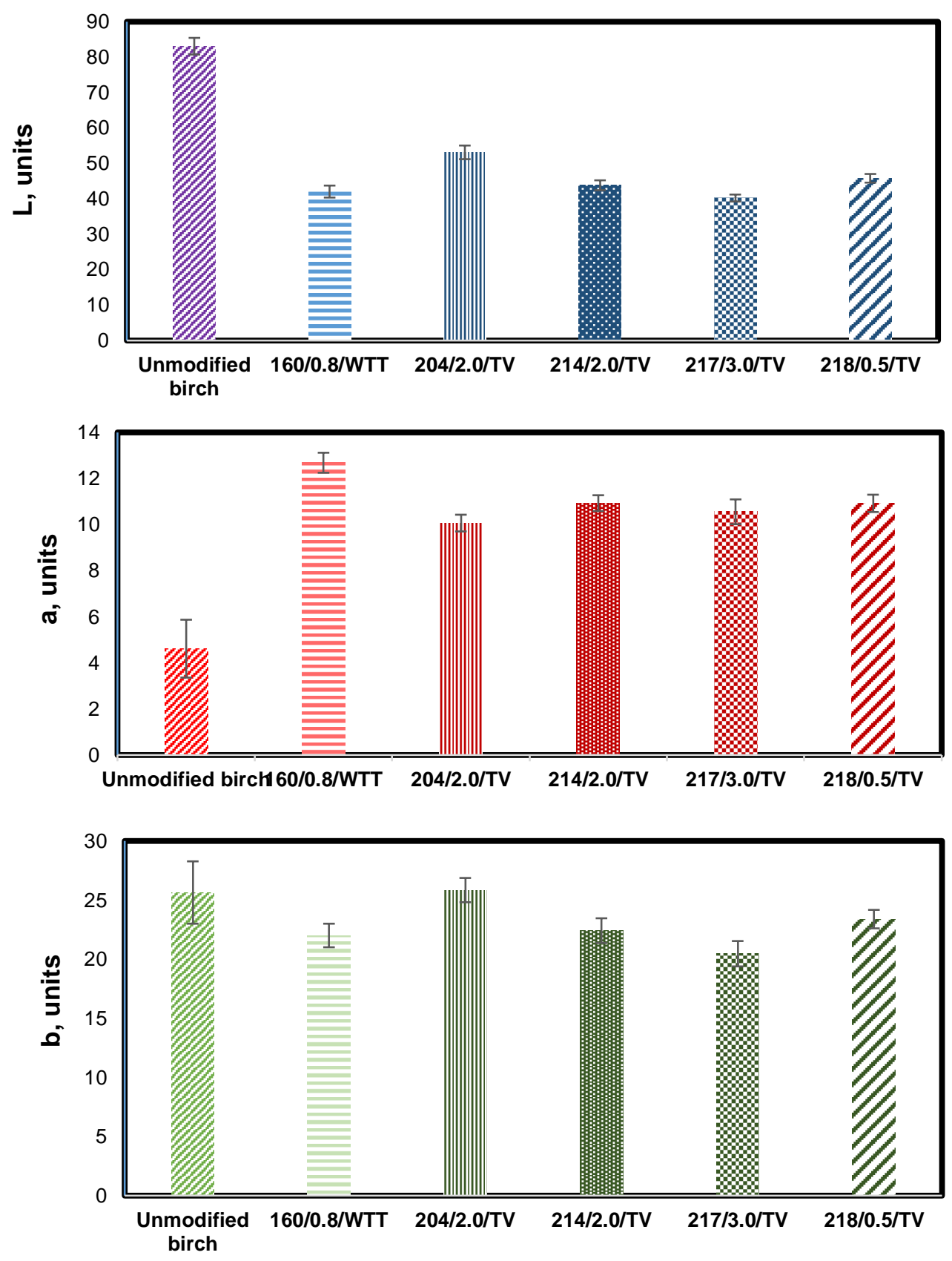

Fig. 2. Color coordinates $L^{*}, a^{*}$, and $b^{*}$ of untreated and treated wood samples at different process conditions (STDEV error bars)

Total color changes in VT and WTT process treated veneers are considerably larger than observed by Barcik et al. (2015) - in the Termowood® process. For birch treated at $160{ }^{\circ} \mathrm{C} \Delta E$ was 1.16 , and at $210^{\circ} \mathrm{C}$ it was 2.56 . Using the birch thermal modification under saturated $160{ }^{\circ} \mathrm{C}$ and superheated $185^{\circ} \mathrm{C}$ steam, Torniainen et al. (2011) showed that $L^{*}$ decreased from 80.92 to 52.72 and 55.48 accordingly, which coincides with the findings of this research. 


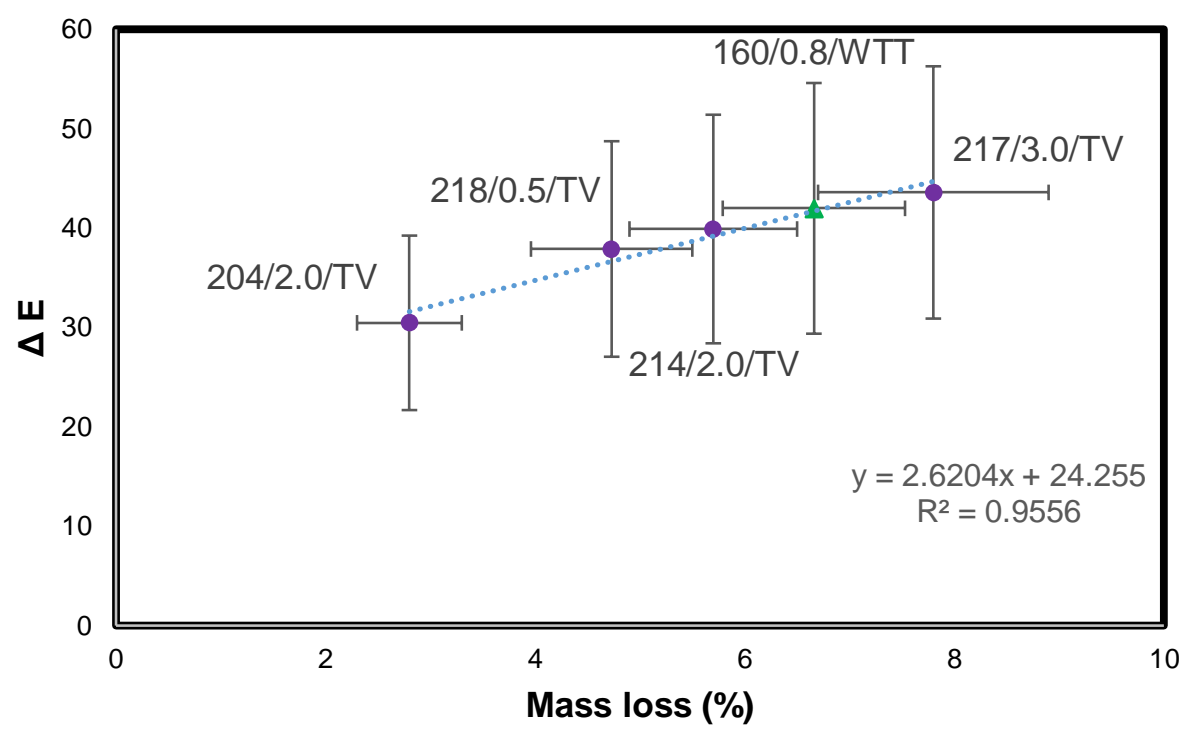

Fig. 3. Total color change $(\Delta E)$ correlation with mass loss during thermal modification

\section{Equilibrium Moisture Content (EMC) and Moisture Exclusion Efficiency (MEE)}

As shown in Fig. 4, the treated wood had a lower EMC compared to wood that was not treated. The veneers treated at 204/2.0/TV were the most hygroscopic at all $\mathrm{RH}$. The least hygroscopic materials were 160/0.8/WTT and 217/3.0/TV. It is commonly known that hydrothermally-treated wood becomes less hygroscopic (Mirzaei et al. 2017). Water uptake of wood is reduced by the heat-treatment process (Hyttinen et al. 2010), since hemicellulose and cellulose are the main wood components responsible for decay and hygroscopicity of wood (Li et al. 2017).

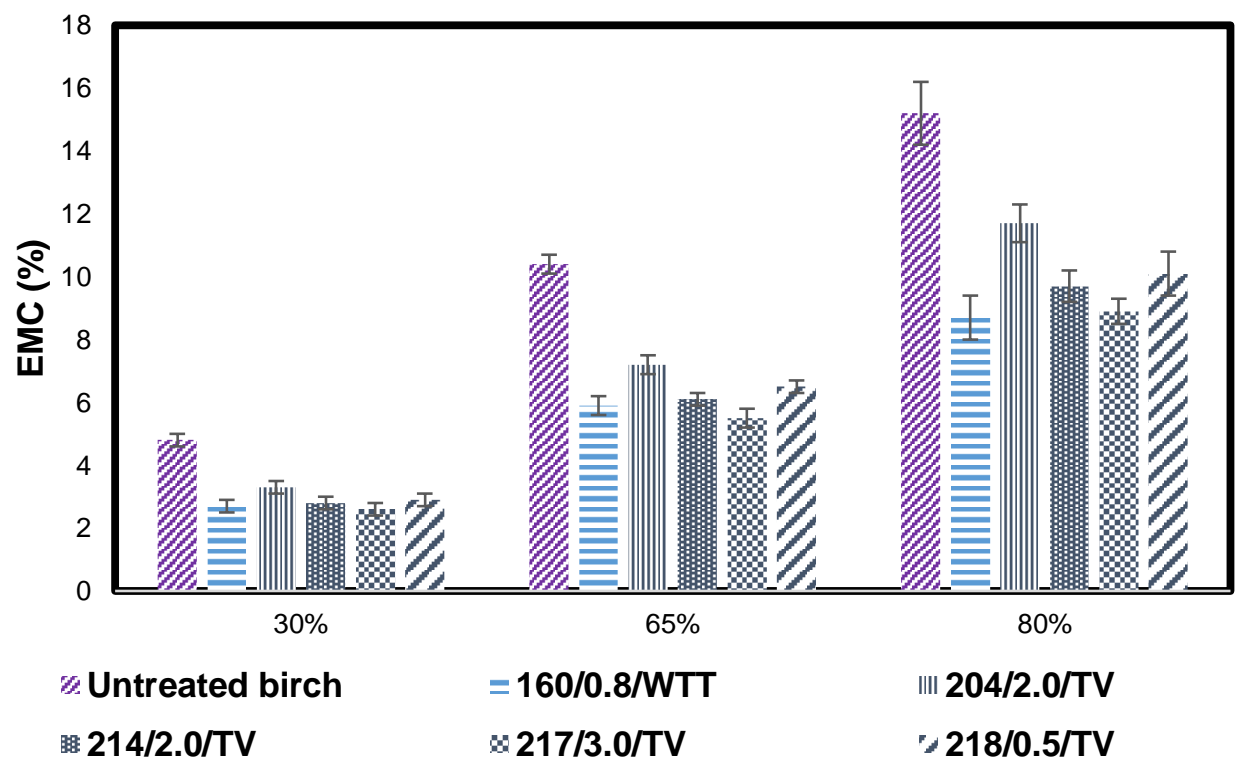

Fig. 4. The equilibrium moisture content at a different relative humidity of untreated and treated birch veneer samples (STDEV error bars) 
The moisture content of heat-treated wood was about half compared to that of untreated wood. Because of the loss of hygroscopic hemicellulose sugars and their conversion to less hygroscopic furan-based polymers, predominantly furfural and hydroxymethylfurfural, during heat treatment, the equilibrium moisture content was reduced to about half the value of untreated wood (Jämsä et al. 2000; Sandberg et al. 2013), which coincided with the results in Fig. 4.

The MEE characterized the increase in the modified veneers` hydrophobicity. The results can be seen in Table 3. 217/3.0/TV was the most hydrophobic due to the more severe treatment conditions among all TV treatments. MEE correlated well with mass loss at $\mathrm{RH} 30 \%(\mathrm{r}=0.99)$, at $\mathrm{RH} 65 \%(\mathrm{r}=0.99)$ and at $\mathrm{RH} 80 \%(\mathrm{r}=0.95)$.

Table 3. MEE of Process Conditions at Different Relative Humidity

\begin{tabular}{|l|c|c|c|}
\hline Treatments & $\mathrm{RH} 30 \%$ & $\mathrm{RH} 65 \%$ & $\mathrm{RH} 80 \%$ \\
\hline $160 / 0.8 / \mathrm{WTT}$ & $-42.8 \%$ & $-43.4 \%$ & $-42.9 \%$ \\
\hline $204 / 2.0 /$ TV & $-31.3 \%$ & $-30.7 \%$ & $-23.5 \%$ \\
\hline $214 / 2.0 /$ TV & $-41.3 \%$ & $-41.8 \%$ & $-36.5 \%$ \\
\hline $217 / 3.0 /$ TV & $-45.6 \%$ & $-47.0 \%$ & $-41.3 \%$ \\
\hline $218 / 0.5 /$ TV & $-38.8 \%$ & $-37.8 \%$ & $-34.0 \%$ \\
\hline
\end{tabular}

\section{Tensile Strength}

The results of tensile strength properties along fibers are reported in Fig. 5. The data had considerably high standard deviations, but the mean values of tensile strength were compared to the values for untreated birch, and there was no remarkable difference, such as $117 \mathrm{MPa}$ in this research compared to $125.5 \mathrm{MPa}$ according to Grinins (2016), although this was over $20 \%$ higher than $75 \mathrm{MPa}$ as shown in literature (Volynsky 2009).

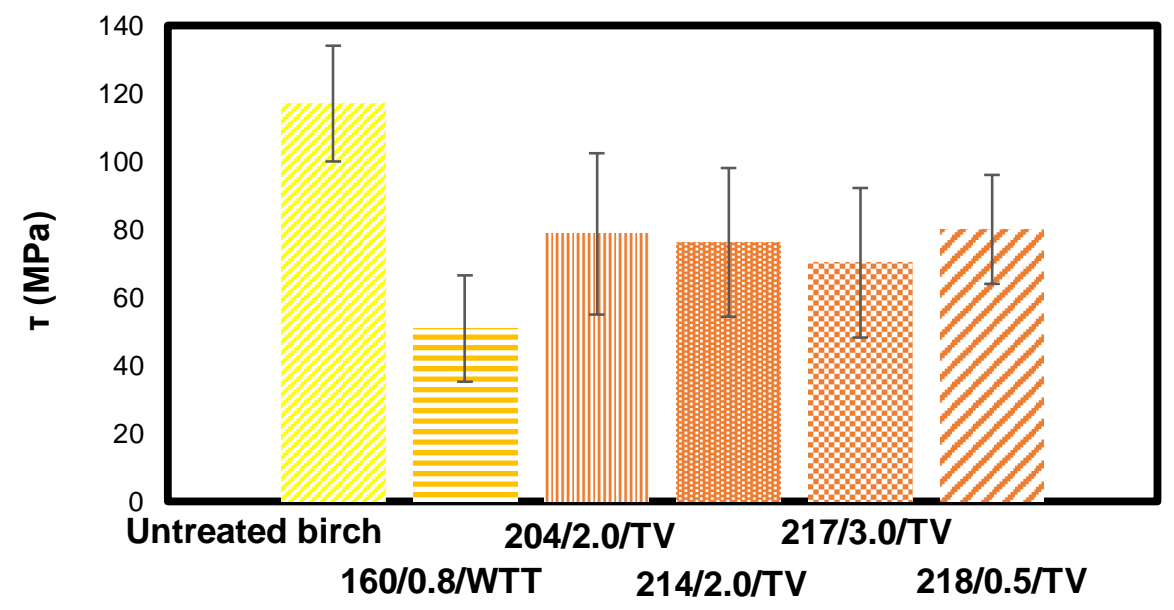

Fig. 5. Tensile strength along fibers of untreated and treated birch veneers (STDEV error bars)

The state of the wood cell wall directly affected the veneers`strength properties. As a result of the degradation of hemicelluloses, the wood becomes brittle and rigid, which indicates the important role that hemicelluloses have in imparting viscoelastic properties to wood (Hill 2006). After the thermal modification of birch veneers in the TV process, the tensile strength along the fibers decreased from $117 \mathrm{MPa}$ to approximately $76 \mathrm{MPa}$ apart 
from treatment regime. In the WTT process, the tensile strength decreased to approximately $51 \mathrm{MPa}$. Strength loss in the WTT process was considerably greater than in the TV process. The tensile strength fairly correlated with mass loss $(r=0.57)$, and for the TV-treated samples it was notable $(r=0.86)$. As shown in Fig. 6, the WTT-treated veneers differed from the TV - treated veneers.

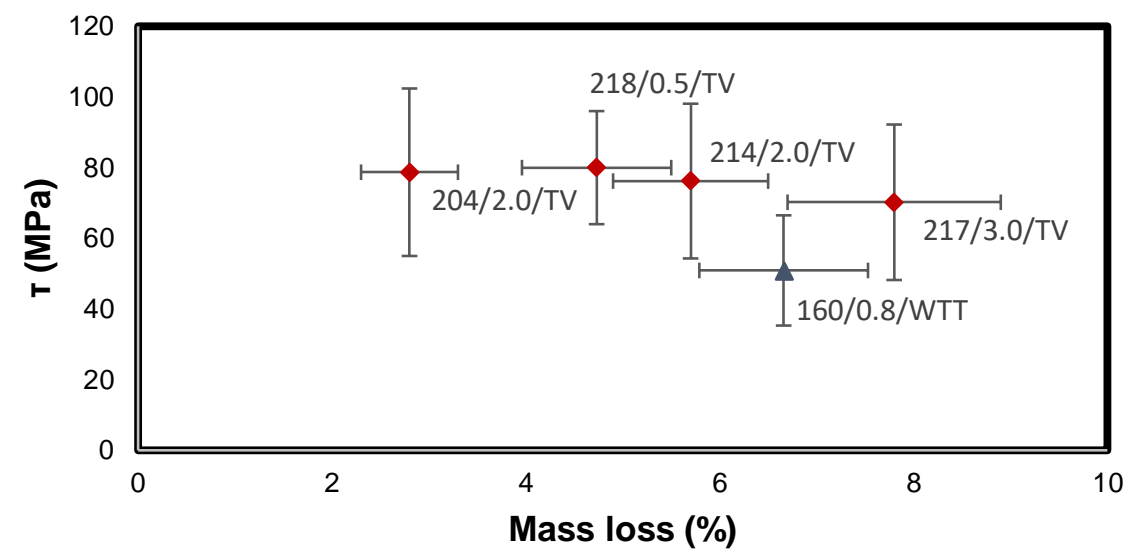

Fig. 6. Mass loss correlation of tensile strength of treated birch veneer samples (STDEV error bars)

\section{Decay Resistance}

Figure 7 shows that none of the veneers could be considered durable according to the ENV 12038 (2002). Weight loss for all the samples exceeded 3\%. The 217/3.0/TV veneers were the most durable, with weight loss of $12.1 \pm 3.4 \%$. The $160 / 0.8 /$ WTT and 204/2.0/TV treatments did not provide any improvements in durability compared to untreated birch veneers.
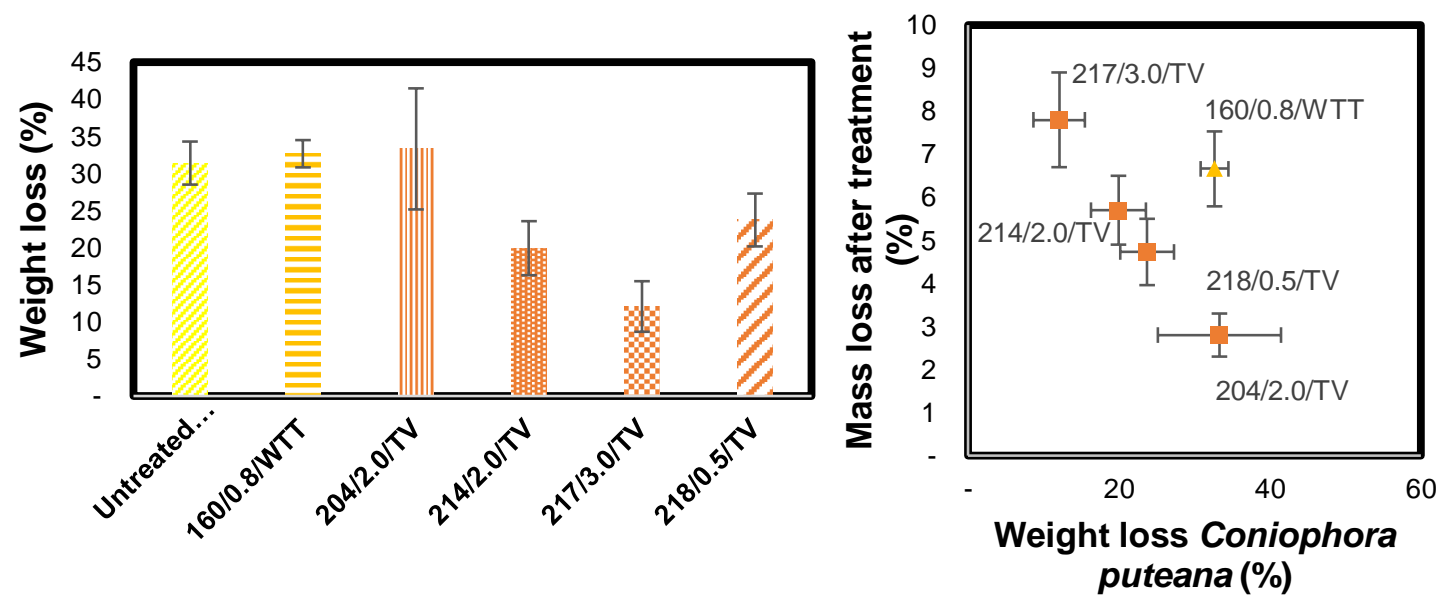

Fig. 7. Weight loss after fungus Coniophora puteana and its correlation with a mass loss after thermal treatment (STDEV error bars)

The TV treated veneers showed a high correlation between mass loss after thermal treatment and durability $(\mathrm{r}=0.97)$. Although $160 / 0.8 / \mathrm{WTT}$ had relatively high mass loss after thermal treatment, its durability was comparable with untreated samples with $33 \pm 2 \%$ weight loss, which coincided with $31 \pm 13 \%$ weight loss from the previous findings (Grinins et al. 2016). 


\section{Microscopy}

The color changes were observed to light brown in all TV regimes and dark brown in WTT process in comparison with untreated light silver birch sample (Fig. 2). The treated birch was the most affected by treatment processes $217 / 3.0 / \mathrm{TV}$ - cell walls became thinner - red arrow and 160/0.8/WTT cell walls became fluffy or sharp less - orange arrow, as shown in Fig. 8.

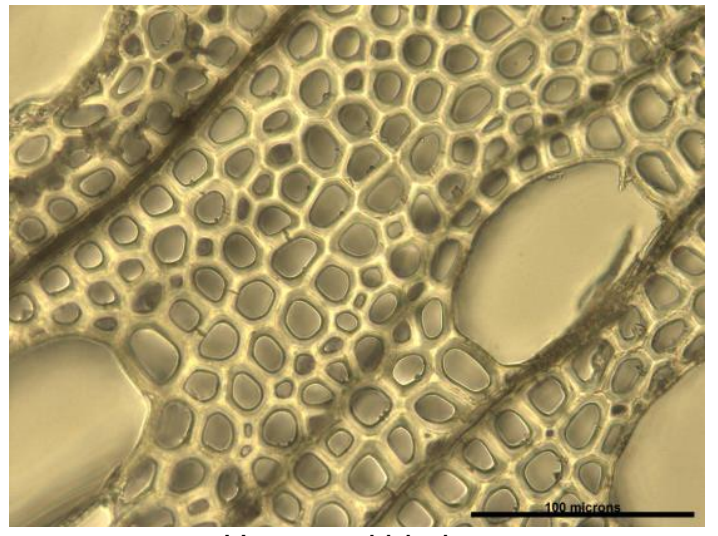

Untreated birch

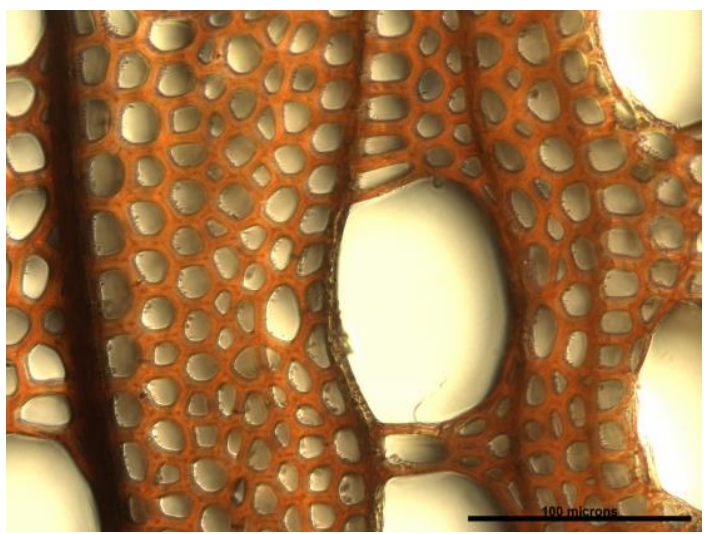

214/2.0/TV

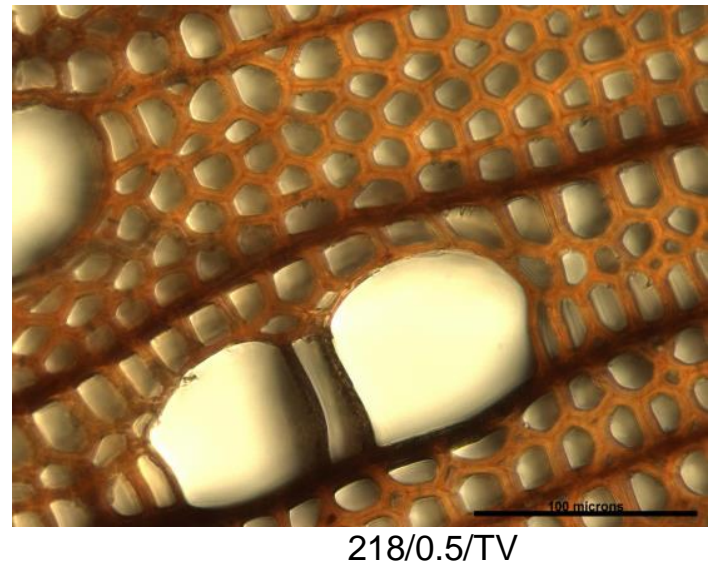

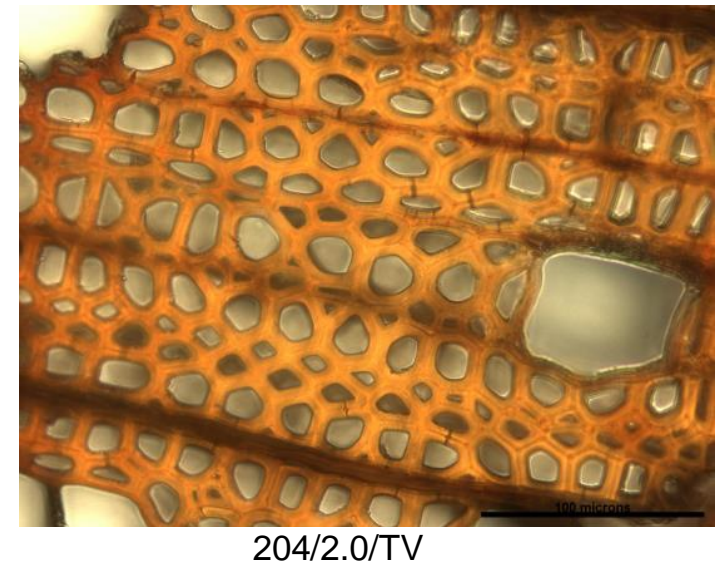
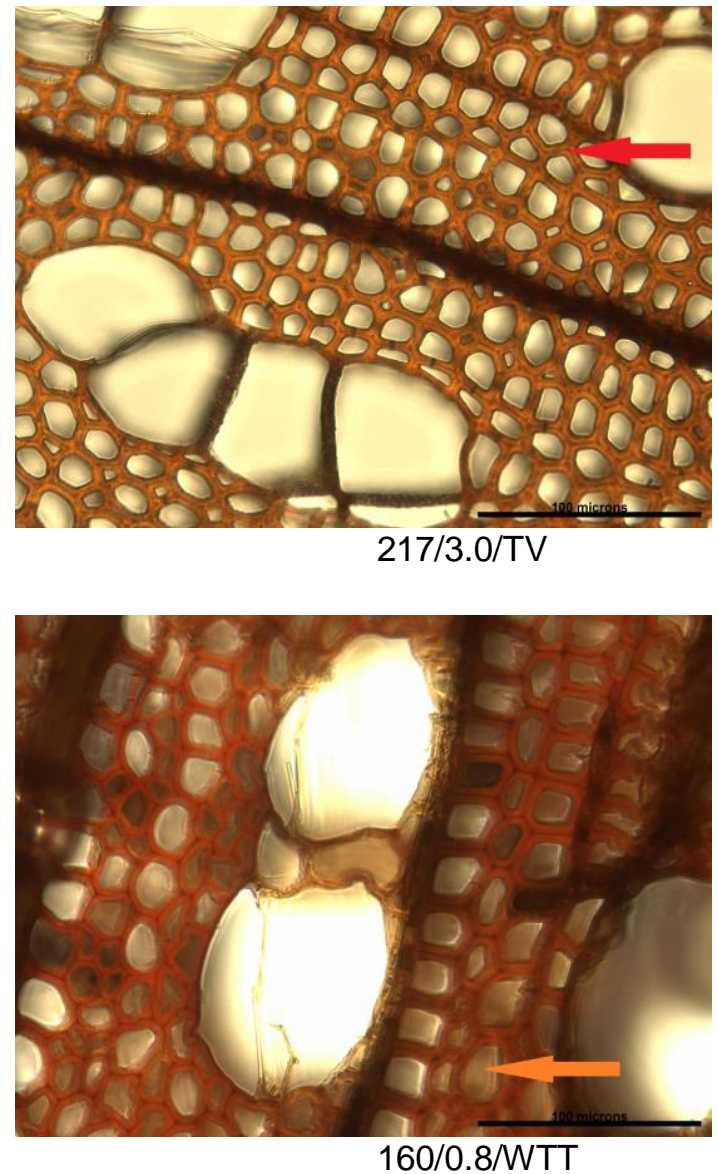

Fig. 8. Cross-section before and after thermal treatment, LM, $\times 400$. Bar $=100 \mu \mathrm{m}$ 
The shrinkage of fiber cell walls was observed in both treatment regimes. The thermally modified samples, especially for treatment regimes 217/3.0/TV and 160/0.8/WTT, were more brittle than their untreated counterparts. This coincides with the findings by Ahmed et al. (2013) determining that increased brittleness due to the modification process has an impact on tensile strength of treated samples (Fig. 5). During thermal modification, middle lamella did not disappear because it consisted mainly of lignin (70\% to $90 \%$ ), which was a more thermally stable wood component. Birch is diffuseporous wood and has sparse apotracheal parenchyma (Schoch et al. 2004). Besides, regime $160 / 0.8$ /WTT caused deformation of the vessels and fibers due to the increased pressure and moist environment during modification. The cellulose framework shrank, and as a result of that the fibers obtained an oval form in the cross-section (Biziks et al. 2013).

\section{CONCLUSIONS}

1. The TV thermal modification process was more suitable for birch (Betula pendula Roth) veneer treatment than the WTT process both in terms of maintaining strength properties and providing durability.

2. Among investigated samples, the regime 217/3.0/TV showed the best resistance against brown rot and acceptable other physical - chemical properties and tensile strength.

3. Treatment regimes with the highest mass loss were 217/3.0/TV (7.8\%) and 160/0.8/WTT (6.7 \%). Mass loss correlated well with the MEE in all the RH environments $(r=0.95$ to 0.99$)$.

4. Veneer color depended on the treatment temperature and time. As expected, veneers became darker during the thermal modification, $L^{*}$ value decreased twice, and $a^{*}$ value increased. Total color change $\Delta E$ correlated $(\mathrm{r}=0.98)$ with the mass loss after the thermal modification.

5. The TV treated veneers showed a high correlation between mass loss after the thermal treatment and durability against brown rot fungus Coniophora puteana $(\mathrm{r}=0.97)$.

\section{ACKNOWLEDGEMENTS}

This research was carried out within the project P5 "Plywood with improved durability," co-financed by the Implementation of Research Program at Latvia University of Life Sciences and Technologies.

\section{REFERENCES CITED}

Ahmed, S. A., Sehlstedt-Persson, M., Hansson, L., and Morén, T. (2013). "Evaluation of preservative distribution in thermally modified European aspen and birch boards using computed tomography and scanning electron microscopy," J. Wood Sci. 59(1), 57-66.

DOI: $10.1007 / \mathrm{s} 10086-012-1299-\mathrm{x}$

Allegretti, O., Brunetti, M., Cuccui, I., Ferrari, S., Nocetti, M., and Terziev, N. (2012). 
"Thermo-vacuum modification of spruce (Picea abies Karst.) and fir (Abies alba Mill.) wood," BioResources 7(3), 3659-3669. DOI: 10.15376/biores.7.3.3659-3669

Barcík, Š., Gašparík, M., Razumov, E.Y. (2015). "Effect of temperature on the color changes of wood during thermal modification," Cellul. Chem. Technol. 49, 789-798.

Biziks, V., Andersons, B., Beḷkova, L,., Kapača, E., and Militz, H. (2013). "Changes in the microstructure of birch wood after hydrothermal treatment," Wood Sci. Technol. 47(4), 717-735. DOI: 10.1007/s00226-013-0531-1

Biziks, V., Van den Bulcke, J., Grinins, J., Militz, H., Andersons, B., Andersone, I., Dhaene, J., and Van Acker, J. (2016). "Assessment of wood microstructural changes after one-stage thermo-hydro treatment (THT) by micro X-ray computed tomography," Holzforschung 70(2), 167-177. DOI: 10.1515/hf-2014-0337

Brischke, C., Welzbacher, C.R., Brandt, K., Rapp, A.O. (2007). "Quality control of thermally modified timber: Interrelationship between heat treatment intensities and CIE L*a*b* color data on homogenized wood samples," Holzforschung. 61. DOI: 10.1515/HF.2007.004

Candelier, K., Dumarçay, S., Pétrissans, A., Desharnais, L., Gérardin, P., and Pétrissans, M. (2013). "Comparison of chemical composition and decay durability of heat treated wood cured under different inert atmospheres: Nitrogen or vacuum," Polym. Degrad. Stab. 98(2), 677-681. DOI: 10.1016/j.polymdegradstab.2012.10.022

Chaouch, M., Dumarçay, S., Pétrissans, A., Pétrissans, M., and Gérardin, P. (2013). "Effect of heat treatment intensity on some conferred properties of different European softwood and hardwood species," Wood Sci. Technol. 47(4), 663-673. DOI: $10.1007 / \mathrm{s} 00226-013-0533-\mathrm{z}$

ENV 12038 (2002). "Durability of wood and wood-based products - Wood-based panels - Method of test for determining the resistance against wood-destroying basidiomycetes," European Committee for Standardization, Brussels, Belgium.

Esteves, B. M., and Pereira, H. M. (2009). "Wood modification by heat treatment: A review," BioResources 4(1), 370-404. DOI: 10.15376/biores.4.1.370-404

Ferrari, S., Cuccui, I., and Allegretti, O. (2013). "Thermo-vacuum modification of some European softwood and hardwood species treated at different conditions," BioResources 8(1), 1100-1109. DOI: 10.15376/biores.8.1.1100-1109

Gérardin, P. (2016). "New alternatives for wood preservation based on thermal and chemical modification of wood - A review," Ann. For. Sci. 73(3), 559-570. DOI: 10.1007/s13595-015-0531-4

Gilbert, B. P., Bailleres, H., Fischer, M. F., Zhang, H., and McGavin, R. L. (2017). "Mechanical properties of rotary veneers recovered from early to mid rotation subtropical-hardwood plantation logs for veneer-based composite applications." $J$. Mater. Civ. Eng. 29. DOI: 10.1061/(ASCE)MT.1943-5533.0002055

GOST 20800-75. (1976). "Rotary cut veneer. Test methods," State Standard of the Soviet Union.

Grinins, J. (2016). Bērza saplākšn,a īpašību uzlabošana ar hidrotermiskās modifikācijas pañēmienu [Improvement of Properties of Birch Plywood with Thermo-Hydro Treatment Method], Doctoral Thesis, Riga Technical University, Riga, Latvia Grinins, J., Andersons, B., Irbe, I., Andersone, I., Meija-Feldmane, A., Janberga, A., Pavlovics, G., and Sansonetti, E. (2016). "Thermo-hydro treated (THT) birch veneers for producing plywood with improved properties," Holzforschung 70(8), 739-746. DOI: $10.1515 / \mathrm{hf}-2015-0155$

Hildebrandt, J., Hagemann, N., and Thrän, D. (2017). “The contribution of wood-based 
construction materials for leveraging a low carbon building sector in Europe," Sustain. Cities Soc. 34, 405-418. DOI: 10.1016/j.scs.2017.06.013

Hill, C. (2006). "Thermal modification of wood," in Wood Modification: Chemical, Thermal and Other Processes, John Wiley \& Sons, Chichester, United Kingdom, pp. 99-127. DOI: 10.1002/0470021748.ch5

Hon, D., and Minemura, N. (2001). "Colour and discolouration," in: Wood and Cellulosic Chemistry, D. N.-S. Hon and N. Shiraishi (eds.), Marcel Dekker, New York, NY, pp. 385-442.

Hyttinen, M., Masalin-Weijo, M., Kalliokoski, P., and Pasanen, P. (2010). “Comparison of VOC emissions between air-dried and heat-treated Norway spruce (Picea abies), Scots pine (Pinus sylvestris) and European aspen (Populus tremula) wood," Atmos. Environ. 44(38), 5028-5033. DOI: 10.1016/j.atmosenv.2010.07.018

ISO 13061-1. (2014). "Physical and mechanical properties of wood - Test methods for small clear wood specimens - Part 1: Determination of moisture content for physical and mechanical tests," International Organization for Standardization, Geneva, Switzerland.

ISO 13062-2. (2014). "Physical and mechanical properties of wood - Test methods for small clear wood specimens - Part 2: Determination of density for physical and mechanical tests," International Organization for Standardization, Geneva, Switzerland.

ISO/CIE 11664-4. (2008). “Colorimetry - Part 4: CIE 1976 L*a*b* Colour space," International Commission on Illumination, Vienna, Austria.

Irbe, I., Grinins, J., Andersons, B., Andersone, I. (2017). "Durability of thermo-hydro treated (THT) birch veneers and plywood," Pro ligno. 13 (4), 115-122.

Jämsä, S., Ahola, P., and Viitaniemi, P. (2000). "Long-term natural weathering of coated ThermoWood," Pigm. Resin Technol. 29(2), 68-74. DOI: 10.1108/03699420010317807

Kotilainen, R. (2000). Chemical Changes in Wood During Heating at $150-260{ }^{\circ} \mathrm{C}$, Ph.D. Thesis, Jyväskylä Universitiy, Jyväskylä, Finland.

Li, T., Cheng, D., Avramidis, S., Wålinder, M. E. P., and Zhou, D. (2017). "Response of hygroscopicity to heat treatment and its relation to durability of thermally modified wood," Constr. Build. Mater. 144, 671-676. DOI:

10.1016/J.CONBUILDMAT.2017.03.218

Lovrić, A., Zdravković, V., and Furtula, M. (2014). "Influence of thermal modification on colour of poplar (Populus x euramericana) rotary cut veneer," Wood Res. 59(4), 661-670.

Mirzaei, G., Mohebby, B., and Ebrahimi, G. (2017). "Glulam beam made from hydrothermally treated poplar wood with reduced moisture induced stresses," Constr. Build. Mater. 135, 386-393. DOI: 10.1016/J.CONBUILDMAT.2016.12.178

Mokrzycki, W. and Tatol, M. (2011). "Color difference Delta E - A survey," Machine Graphics and Vision 20(4), 383-411.

Raute. (2017). "Plywood production and consumption," (https://www.raute.com/documents/10157/880369/Plywood+production+and+consum ption_20171031+update.pdf), Accessed 30 September 2019.

Rep, G., Pohleven, F., and Košmerl, S. (2012). "Development of industrial kiln for thermal wood modification by a procedure with initial vacuum and commercialisation of modified Silvapro ${ }^{\circledR}$ wood," in: European Conference on Wood Modification, D. Jones, H. Militz, M. Petrič, F. Pohleven, M. Humar, M. Pavlič (eds.), Ljubljana, 
Slovenia, pp. 13-20.

Ruponen, J., Črmák, P., Rhême, M., and Rautkari, L. (2015). "Reducing the moisture sensitivity of linear friction welded birch (Betula pendula L.) wood through thermal modification," J. Adhes. Sci. Technol. 29(22), 2461-2474. DOI:

10.1080/01694243.2015.1069721

Sandak, A., Allegretti, O., Cuccui, I., Sandak, J., Rosso, L., Castro, G., Negro, F., Cremonini, C., and Zanuttini, R. (2016). "Thermo-vacuum modification of poplar veneers and its quality control," BioResources 11(4), 10122-10139. DOI: 10.15376/biores. 11.4.10122-10139

Sandak, A., Sandak, J., and Allegretti, O. (2015). "Quality control of vacuum thermally modified wood with near infrared spectroscopy," Vacuum 114, 44-48. DOI: 10.1016/j.vacuum.2014.12.027

Sandberg, D., Haller, P., and Navi, P. (2013). "Thermo-hydro and thermo-hydromechanical wood processing: An opportunity for future environmentally friendly wood products," Wood Mater. Sci. Eng. 8(1), 64-88. DOI: 10.1080/17480272.2012.751935

Sandberg, D., and Kutnar, A. (2016). "Thermal modified timber (TMT): Recent development in Europe and North America," Wood Fiber Sci. 48, 28-39.

Sandberg, D., Kutnar, A., and Mantanis, G. (2017). "Wood modification technologies - A review," iForest Biogeosci. For. 10(6), 895-908. DOI: 10.3832/ifor2380-010

Schoch, W., Heller, I., Schweingruber, F. H., and Kienast, F. (2004). "Wood anatomy of central European Species," (http://www.woodanatomy.ch), Accessed 15 September 2019.

Shi, J. L., Kocaefe, D., and Zhang, J. (2007). "Mechanical behaviour of Québec wood species heat-treated using ThermoWood process," Holz Roh-Werkst. 65(4), 255-259. DOI: 10.1007/s00107-007-0173-9

Torniainen, P., Dagbro, O., Morén, T. (2011). "Thermal Modification of Birch Using Saturated and Superheated Steam." in: Proceedings of the 7th Meeting of NordicBaltic Network in Wood Material Science and Engineering 2011, 27-28 October, Oslo, pp. 43-48.

Van Acker, J., Michon, S., Van den Bulcke, J., De Windt, I., Van Swaay, B., and Stevens, M. (2011). "Limited variability in biological durability of thermally modified timber using vacuum based technology," International Research Group on Wood Preservation, IRG/WP 11-40567.

Volynsky, V. N. (2009). Technology of Glued Materials, Профви, St. Petersburg, Russia. Xu, J., Zhang, Y., Shen, Y., Li, C., Wang, Y., Ma, Z., and Sun, W. (2019). 'New perspective on wood thermal modification: Relevance between the evolution of chemical structure and physical-mechanical properties, and online analysis of release of VOCs," Polymers 11(7), 1145. DOI: 10.3390/polym11071145

Article submitted: December 19, 2019; Peer review completed: February 22, 2020; Revised version received and accepted: April 11, 2020; Published: April 15, 2020. DOI: $10.15376 /$ biores. 15.2.4150-4164 